\title{
Space-time scan statistics of 2007-2013 dengue incidence in Cimahi city, Indonesia
}

\author{
Pandji Wibawa Dhewantara,' Andri Ruliansyah,' ${ }^{1}$ M. Ezza Azmi Fuadiyah, ${ }^{1}$ \\ Endang Puji Astuti, ${ }^{1}$ Mutiara Widawati, ${ }^{1,2}$ \\ ${ }^{1}$ National Institute of Health Research and Development, Unit of Vector-borne Diseases Control, \\ Pangandaran, West Java, Indonesia; ${ }^{2}$ School of Public Health, University of Sydney, Australia
}

\begin{abstract}
Dengue fever threatens more than 200 million people in Indonesia. The disease has spread to over 400 of Indonesia's 497 districts, 26 of which have been declared hyper-endemic. These districts are all situated in West Java, the most densely populated province in the country. A study was conducted to detect clusters of dengue incidence during 2007-2013 in Cimahi City, which is situated in the Bandung metropolitan area in West Java. A temporal-spatial analysis based on population data from the local Bureau of Statistics, and monthly analysis of dengue incidence from the local Municipality Health Office, were performed using SaTScan ${ }^{\mathrm{TM}}$. This retrospective space-time analysis with
\end{abstract}

Correspondence: Pandji Wibawa Dhewantara, National Institute of Health Research and Development, Unit of Vector-borne Diseases Control, Jl. Raya Pangandaran Km.03, Pangandaran 46396, West Java, Indonesia.

Tel: +62.81395242582/+62265-639375 - Fax: +62265-639375.

E-mail: p.dhewantara@gmail.com/panji@litbang.depkes.go.id

Key words: Dengue; Space-time analysis; Cluster analysis; Indonesia.

Contributions: PWD, conceived and designed the study and prepared the manuscript writing, data analysing, references search; AR, GIS processing; MEAF, data collecting, data analysing, manuscript reviewing; EPA, manuscript reviewing, references search; MW, manuscript reviewing. All authors contributed to subsequent revisions and approved the final version.

Conflict of interest: the authors declare no potential conflict of interest.

Acknowledgements: we would like to express our sincere gratitude to West Java Provincial Health Office and Cimahi Municipal Health Office for providing data and information. We are also grateful to Martin Kulldorff for assistance on software operation.

Received for publication: 7 May 2015.

Revision received: 23 September 2015.

Accepted for publication: 16 October 2015.

(C) Copyright P.W. Dhewantara et al., 2015

Licensee PAGEPress, Italy

Geospatial Health 2015; 10:373

doi:10.4081/gh.2015.373

This article is distributed under the terms of the Creative Commons Attribution Noncommercial License (by-nc 3.0) which permits any noncommercial use, distribution, and reproduction in any medium, provided the original author(s) and source are credited. a Poisson distribution model and monthly precision revealed 24 significant clusters $(\mathrm{P}<0.001)$ throughout the seven-year study period. The most likely cluster was detected in the centre of Cimahi City and followed as it moved to the northern part of the city. Several primary and secondary clusters were identified in villages surrounding Cimahi City over time, and our conclusion is that we identified a dynamic spread of dengue fever initiated from the city centre to surrounding areas during the study period. In general, clusters were more common in the first quarter of each year. An in-depth investigation to understand relevant risk factors in high-risk areas in Cimahi city is encouraged.

\section{Introduction}

Dengue fever (DF) is an arboviral, vector (Aedes mosquitoes)-borne disease that exists in four serotypes (DEN 1-4), which threatens more than 2.5 billion of the world's population. Globally, DF has increased to more than 30 times in last 50 years, resulting in more than 50-100 million infections annually (WHO, 2011; Bhatt et al., 2013). It is known that the dengue virus spreads rapidly due to a high adaptive tendency of the Aedes species, climate change, common areas suitable as breeding sites, strong population mobility and international trade (McMichael et al., 2006; Benedict et al., 2007; Aranuchalam et al., 2010; Gubler, 2011; Schmidt et al., 2011; Bouzid et al., 2014). Knowledge on epidemiological trends of the dengue virus, both spatially and temporally, in the hyper-endemics is needed to strengthen current control and prevention (Attaway et al., 2014). This is particularly important as there is currently no chemotherapy or vaccines available, even if a potentially useful vaccine comes on the market in the next five years (Lang, 2009).

The first DF outbreak Indonesia was reported in Surabaya in 1968 (Sumarmo, 1987). The four circulating DEN serotypes have resulted in outbreaks in 412 of Indonesia's 497 districts. All DEN serotypes have been documented in West Java with the DEN-3 type being the predominant one (Prasetyowati and Santya, 2012). In 2013, the Ministry of Health of Indonesia (MoHI) reported 112,511 cases (DF incidence rate of 41.25 per 100,000 population) and 871 deaths corresponding to a case fatality rate of $0.7 \%$ (Ministry of Health of Indonesia, 2014). Almost 20\% of the total population live in West Java, which makes it one of the most densely populated province in the country. West Java has 26 districts declared as hyper-endemic (2013 incidence rate: $\mathbf{5 0 . 5 5}$ per 100,000 people; case fatality rate: $0.7 \%$ ). Cimahi City had the highest DF incidence rate in West Java in 2013. For the last ten years, more than 12,000 DF incidence and 84 deaths was reported in the city (Cimahi Municipal Health Office, 2014). Cimahi City is part of the Bandung metropolitan area, which is an endemic region and in the fourth most densely populated city (Porter et al., 2005). Incipient 
insecticide resistance and relevant studies on epidemiological situation regarding the DF spatial-temporal distribution in Indonesia, specifically in Cimahi City, control and prevention remain inadequate (Astuti et al., 2014).

In order to enhance our understanding about distribution and DF trends over time, we performed a retrospective spatial-temporal analysis on DF incidence over 2007-2013 in Cimahi City. However, to our knowledge, this is the first study on spatial-temporal analysis using space-time scan statistics to investigate the DF trend in West Java. This approach for various health-related matters has been documented, both for infectious diseases (DF, malaria, tuberculosis) and non-communicable diseases epidemiology (i.e. cancer) (Kulldorff et al., 1998; Morrison et al., 1998; Touray et al., 2010; Jeefoo et al., 2010; Schmidt et al., 2011; Wu et al., 2011; Bi et al., 2013). Surveillance and early detection should be prioritized in the face of the global DF threat (Guzman et al., 2010). Thus, identification of the distribution pattern of DF cases is required to discover the spread of the disease in Cimahi City. Our study aimed to investigate: i) the presence of high-risk DF clusters in this area; and ii) the temporal distribution pattern of detected such cluster over the seven-year period.

\section{Materials and Methods}

\section{Study site}

With more than 43 million people at an average density of 1222 people per $\mathrm{km}^{2}$, West Java has the highest population in Indonesia (Bureau of Statistics of Indonesia, 2014). Cimahi City comprises three sub-districts or Kecamatan (North Cimahi, Centre Cimahi, and South Cimahi) and fifteen villages known as Kelurahan (Cibabat, Cipageran, Citeureup, Pasirkaliki, Baros. Cigugur Tengah, Cimahi, Karangmekar, Padasuka, Setiamanah, Cibeber, Cibeureum, Leuwigajah, Melong, dan Utama). It should be noted that Cimahi is also the name of a village belonging to the larger entity of Cimahi City. The population density varies in each Kelurahan, from 79.01 to 236.10 people per $\mathrm{km}^{2}$. The city is located around latitude $6^{\circ} 53$ 'S and longitude $107^{\circ} 32^{\prime} \mathrm{E}$ (Figure 1), covers an area of $40.37 \mathrm{~km}^{2}$ and has a total population of 561,368 people (Cimahi Municipal Bureau of Statistics, 2014)

\section{Data}

For the purpose of analysis, we obtained a 7-year period of hospitalconfirmed DF incidence data (2007-2013) from the Cimahi Municipal Health Office. Village-level population data were obtained from the Cimahi Municipal Bureau of Statistics (Cimahi Municipal Bureau of Statistics, 2014). For spatial geo-reference needs, 15 village coordinates (latitute/longitude) were obtained by geo-coding each village offices (Kantor Kelurahan) to represent each geographical location on a Google Maps application.

\section{Spatial-temporal analysis}

We downloaded the free, space-time statistics software SaTScan ${ }^{\mathrm{TM}}$ ver.9.4 (SaTScan, 2015) that was originally developed by Martin Kulldorff (Kulldorff and Nagarwalla, 1995). Applications of this software has been used for various purposes and accordingly documented (Kulldorff et al., 1998; Schmidt et al., 2011; Bi et al., 2013; SaTScan, 2015). In our study, we used retrospective space-time analysis with a Poisson model to identify villages at high risk for DF during between 1 January 2007 and 31 December 2013. By default, the maximum spatial cluster size is set at $50 \%$ of the population at risk to reduce bias (Kulldorff and Nagarwalla, 1995). However, our study used a modified maximum spatial cluster size of $15 \%$ of the total population at risk to avoid overlapping. This was felt to be acceptable considering the high population density and the size of the area selected for study. A circular window shape was chosen and the size of maximum temporal cluster set at $50 \%$ of the total population at risk to detect possible sub-clusters. No space-time trend adjustments were performed. A Monte-Carlo approach with 9999 repetitions was performed to test null hypothesis that there was not difference of relative risk (RR) between DF clusters. $P$ values $<0.0001$ were considered as statistically significant. The cluster with the highest log-likelihood ratio (LLR) was determined as the most likely cluster, while the others with lower LLR defined as secondary clusters (SaTScan, 2015). To visualise the cluster pattern in a geographical context, the geographic information system (GIS) software ArcGIS, version 9.0 (ESRI Inc., Redlands, CA, USA) were used.

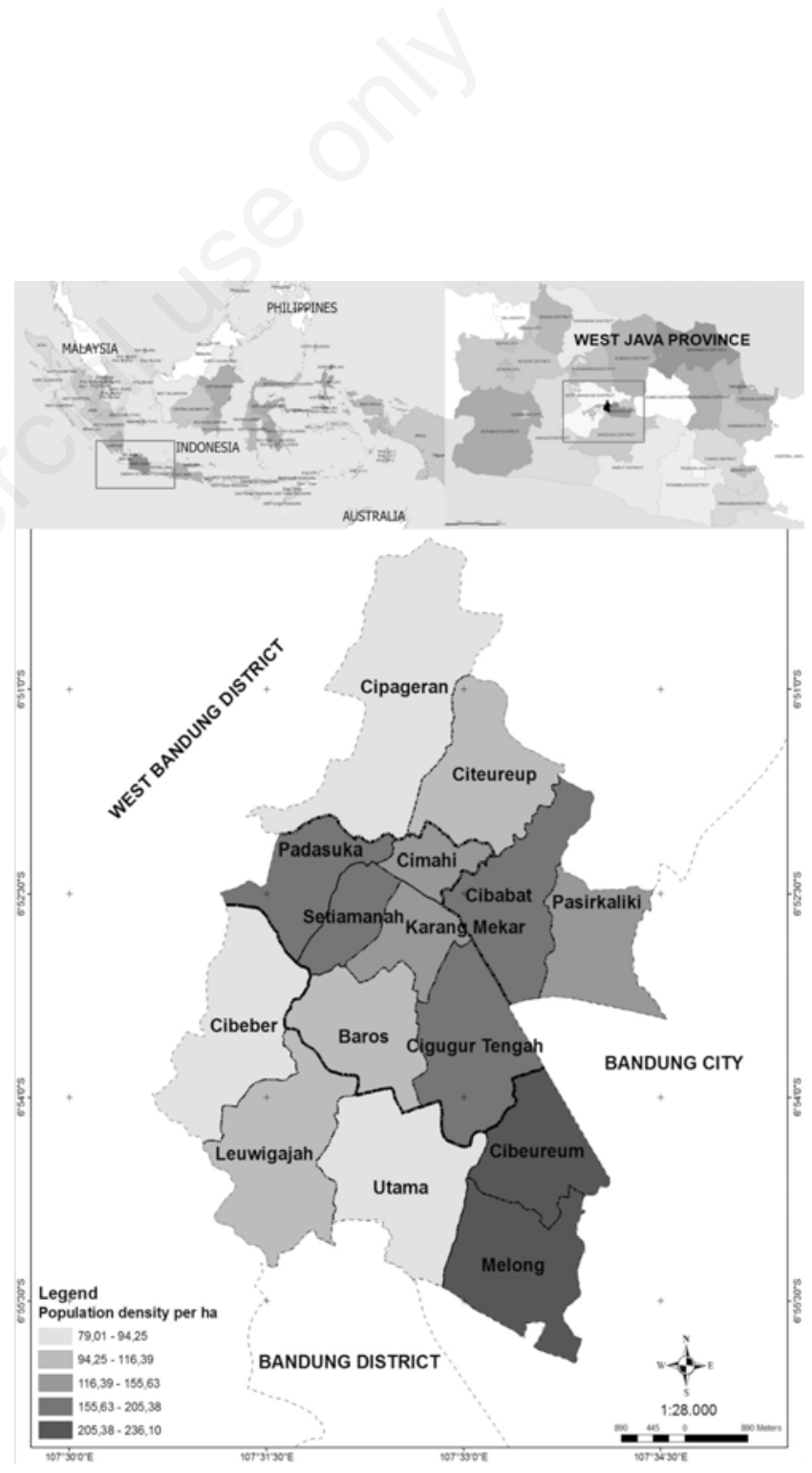

Figure 1. Geographical location of Cimahi City and its surrounding 15 villages. 


\section{Results}

Based on a monthly DF data from the seven-year study period, our space-time analysis detected a total of 24 clusters (Table 1). These DF clusters were initially spatially concentrated in the centre of Cimahi City but moved towards the northern region by the end of the study.

At the first quarter of 2007, we identified seven significant clusters $(\mathrm{P}<0.001)$. A most likely cluster, with RR of 2.16 covered the three villages Cibabat, Cimahi, and Karangmekar $(\mathrm{P}<0.001 ; 12 \%$ of the total population), was discovered. There were six secondary clusters, one of which (Cibeber) had more than three-fold RR than the other clusters. In the second year of study, a most likely cluster, covering Cibabat and Cimahi $(\mathrm{RR}=2.53 ; \mathrm{P}<0.001)$ with more than 50,000 population at risk was detected. However, there were only three secondary clusters this year and they covered the four villages of Cipageran, Citeureup, Baros and Cibeureum. In January-April of 2009, Cibabat and Cimahi along with Padasuka formed a most likely cluster $(R R=2.98 ; 7 \%$ of the total population).

In the first two-months of 2010, a most likely cluster was observed in the three villages of Cimahi, Karangmekar and Setiamanah $(R R=2.96$; $\mathrm{P}<0.001 ; 61,041$ population at risk). The villages Baros, Cipageran and Citeureup were secondary clusters. At the fifth-year of study period, only two clusters were identified, but with greater risk (RR >3.8). They occurred from January-September, d included Citeureup and Cimahi. In February 2012, Citeureup again showed a cluster, but this time with higher relative risk $(\mathrm{RR}=5.77 ; \mathrm{P}<0.001)$. Furthermore, in the first half of 2013 Cipageran was covered by a cluster ( $R R=2.80 ; P<0.001)$. In addition, Cimahi was also identified as a secondary cluster in both mid-
2012 and mid-2013 with a high relative risk documented in 2013 ( $\mathrm{RR}=4.55 ; \mathrm{P}<0.001 ; 14,879$ population at risk). All clusters found are depicted in Figure 2.

\section{Discussion}

Statistically significant high-risk DF clusters with various RR were discovered in almost all villages in the Cimahi City in the seven-year period 2007-2013 and a retrospective space-time analysis detected 24 additional significant clusters $(\mathrm{P}<0.001)$. A dynamic distribution of most likely clusters was seen to spread from the centre of Cimahi City northwards. We found that two of the villages, Cibabat and Cimahi, were most frequently detected as covered by most likely clusters, specifically during the first four years of the study. Citeureup emerged as a most likely cluster in 2011-2013. Temporally, most likely clusters were observed in the first quarter of the year. Most most-likely-cluster geographically centred on a high-populated area with crowded housing situated adjacent to the provincial main road connecting Cimahi City with its neighbours, West Bandung District and Bandung City. Our findings show an evidence of a significant spatio-temporal distribution of DF high-risk areas in the study area.

Although there is still limited use of applied spatio-temporal techniques to understand DF epidemiology in Indonesia, some studies had started to apply GIS approaches. For example, Astutik et al. (2011) used Moran's autocorrelation for DF study in East Java, whereas others have used descriptive GIS and/or remote sensing techniques to document DF in some endemic districts in West Java, such as Ciamis and Banjar

Table 1. Space-time cluster analysis with monthly precision of dengue incidence for Cimahi City 2007-2013.

\begin{tabular}{|c|c|c|c|c|c|c|c|c|c|c|}
\hline Year & Cluster type & $\begin{array}{l}\text { Area } \\
\text { (village level) }\end{array}$ & Period & $\begin{array}{l}\text { Radius } \\
\text { (km) }\end{array}$ & $\begin{array}{l}\text { Actual cases } \\
\text { (n) }\end{array}$ & $\begin{array}{l}\text { Expected } \\
\text { cases (n) }\end{array}$ & $\begin{array}{c}\text { People at risk } \\
\text { (n) }\end{array}$ & $\mathbf{R R}$ & LLR & $\mathbf{P}$ \\
\hline \multirow[t]{7}{*}{2007} & Most likely & Cibabat, Cimahi, Karangmekar & $1 / 1 / 2007-30 / 4 / 2007$ & 1.44 & 224 & 109 & 71,048 & 2.16 & 49.31 & $<0.001$ \\
\hline & $1^{\text {st }}$ secondary & Padasuka, Setiamanah & $1 / 1 / 2007-28 / 2 / 2007$ & 1.41 & 122 & 46.16 & 61,203 & 2.73 & 43.97 & $<0.001$ \\
\hline & $2^{\text {nd }}$ secondary & Cibeber & $1 / 1 / 2007-28 / 2 / 2007$ & 0 & 54 & 15.07 & 19,984 & 3.64 & 30.30 & $<0.001$ \\
\hline & $3^{\text {rd }}$ secondary & Cigugur Tengah & $1 / 2 / 2007-31 / 7 / 2007$ & 0 & 203 & 114.57 & 49,514 & 1.84 & 29.43 & $<0.001$ \\
\hline & $4^{\text {th }}$ secondary & Cipageran & $1 / 1 / 2007-28 / 2 / 2007$ & 0 & 76 & 28.01 & 37,129 & 2.77 & 28.37 & $<0.001$ \\
\hline & $5^{\text {th }}$ secondary & Cibeureum & $1 / 2 / 2007-28 / 2 / 2007$ & 0 & 59 & 22.09 & 61,709 & 2.71 & 21.34 & $<0.001$ \\
\hline & $6^{\text {th }}$ secondary & Utama & $1 / 1 / 2007-28 / 2 / 2007$ & 0 & 67 & 27.55 & 36,527 & 2.47 & 20.42 & $<0.001$ \\
\hline \multirow[t]{4}{*}{2008} & Most likely & Cibabat, Cimahi & $1 / 1 / 2008-30 / 4 / 2008$ & 1.09 & 106 & 44.08 & 53,411 & 2.53 & 32.68 & $<0.001$ \\
\hline & $1^{\text {st }}$ secondary & Cipageran, Citeureup & $1 / 1 / 2008-31 / 3 / 2008$ & 0.74 & 94 & 41.96 & 67,608 & 2.34 & 24.89 & $<0.001$ \\
\hline & $2^{\text {nd }}$ secondary & Baros & $1 / 1 / 2008-31 / 5 / 2008$ & 0 & 58 & 23.99 & 23,144 & 2.49 & 17.65 & $<0.001$ \\
\hline & $3^{\text {rd }}$ secondary & Cibeureum & $1 / 1 / 2008-29 / 2 / 2008$ & 0 & 36 & 12.20 & 61,709 & 3.01 & 15.37 & $<0.00$ \\
\hline \multirow[t]{3}{*}{2009} & Most likely & Padasuka, & $1 / 1 / 2009-30 / 4 / 2009$ & 0 & 140 & 49.25 & 41,600 & 2.98 & 57.61 & $<0.001$ \\
\hline & $1^{\text {st }}$ secondary & Cibabat, Cimahi,Karangmekar & $1 / 1 / 2009-30 / 6 / 2009$ & 1.44 & 255 & 136.5 & 76,440 & 1.99 & 44.62 & $<0.001$ \\
\hline & $2^{\text {nd }}$ secondary & Citeureup & $1 / 1 / 2009-30 / 4 / 2009$ & 0 & 112 & 45.4 & 38,360 & 2.55 & 35.63 & $<0.001$ \\
\hline \multirow[t]{3}{*}{2010} & Most likely & Cimahi, Karangmekar, Setiaman & ahl/1/2010-28/2/2010 & 0.73 & 85 & 29.61 & 61,041 & 2.96 & 35.11 & $<0.001$ \\
\hline & $1^{\text {st }}$ secondary & Baros & $1 / 1 / 2010-31 / 5 / 2010$ & 0 & 74 & 32.04 & 25,806 & 2.37 & 20.48 & $<0.00$ \\
\hline & $2^{\text {nd }}$ secondary & Cipageran, Citeureup & $1 / 1 / 2010-31 / 3 / 2010$ & 0.74 & 102 & 58.66 & 79,267 & 1.78 & 13.63 & $<0.00$ \\
\hline \multirow[t]{2}{*}{2011} & Most likely & Citeureup & 1/1/2011-30/6/2011 & 0 & 49 & 13.92 & 35,182 & 3.81 & 27.94 & $<0.001$ \\
\hline & Secondary & Cimahi & 1/5/2011-30/9/2011 & 0 & 24 & 4.67 & 13,950 & 5.36 & 20.37 & $<0.00$ \\
\hline \multirow[t]{4}{*}{2012} & Most likely & Citeureup & 1/2/2012-29/2/2012 & 0 & 24 & 4.25 & 36,508 & 5.77 & 21.99 & $<0.001$ \\
\hline & $1^{\text {st }}$ secondary & Cigugur Tengah & 1/6/2012-30/6/2012 & 0 & 25 & 6.64 & 55,071 & 3.85 & 14.97 & $<0.00$ \\
\hline & $2^{\text {nd }}$ secondary & Karangmekar, Setiamanah & 1/1/2012-29/2/2012 & 0.53 & 32 & 11.40 & 47,302 & 2.87 & 12.66 & $<0.0$ \\
\hline & $3^{\text {rd }}$ secondary & Cibabat, Cimahi & $1 / 6 / 2012-31 / 8 / 2012$ & 1.09 & 55 & 26.05 & 70,474 & 2.18 & 12.63 & $<0.0$ \\
\hline \multirow[t]{2}{*}{2013} & Most likely & Cipageran, Citeureup & 1/1/2013-30/6/2013 & 0.74 & 129 & 51.34 & 82,438 & 2.80 & 45.38 & $<0.00$ \\
\hline & Secondary & Cimahi & $1 / 8 / 2013-31 / 10 / 2013$ & 0 & 21 & 4.71 & 14,879 & 4.55 & 15.27 & $<0.0$ \\
\hline
\end{tabular}

$\mathrm{RR}$, relative risk; LLR, log likelihood ratio. 
(Ruliansyah et al., 2011, 2014). A Standard Deviational Ellipse (SDE) model was used in Banjar City (Rahmaniati et al., 2014). In contrast, there were numerous studies in mainland Asia applying space-time scan statistics to strengthen DF surveillance system in Malaysia (Cheong et al., 2014), Saudi Arabia (Alzahrani et al., 2013), Thailand (Jeefoo et al., 2010), Bangladesh (Banu et al., 2012), China (Li et al., 2012), and Vietnam (Toan et al., 2013).

Cimahi village, located in the heart of Cimahi City (Figure 1) with 15,563 persons per $\mathrm{km}^{2}$ next to Karangmekar and Cibabat (Cimahi Municipal Bureau of Statistics, 2014), was consistently identified as a most likely cluster between 2007 and 2010 and appeared as a secondary cluster in 2011-2013. These three villages have identical landscape characteristics with dense settlement adjacent to the main road. As an obvious clustered pattern, we found that the high-risk areas spread significantly from the centre to north during the timeframe of the study. A plausible explanation for this phenomenon was that the potential transmission might have occurred in the centre of the city, where most people interacted strongly with each other in schools, offices and market places regardless of having very different health status backgrounds. Occurrence of potential breeding sites in public spaces, vector populations and highly mobile people (commuters) facilitated the spread of DF (Weiss and McMichael, 2004; Wearing and Rohani, 2006). Similar trend has been documented in Thailand, where DF evidently expanded to non-endemic areas (Strickman et al., 2000). Hence, further investigation is needed to identify potential risk factors in these high-risk clusters.
The dynamic spread of high-risk areas within Cimahi City during the seven-year study indicates that there was interrelated association between vector, host, and the environment. For example, many different associations of DF outbreaks with various climate and socio-economic variables have been reported (Johansson et al., 2009; Banu et al., 2011; Åström et al., 2012; Oki and Yamamoto, 2012; Ariati and Musadad, 2013; Naish et al., 2014; Ariati and Anwar, 2014; Bouzid et al., 2014; Dhimal et al., 2015). A study on knowledge, attitude, and practices in Cimahi was performed by Pradani et al. (2010), who concluded that people often show inconsistent preventive measure practices in spite of good perception and knowledge of DF risk factors. A study on vector resistance found that the insecticide cypermethrin was no longer effective when used to control Aedes aegypti populations in Cimahi City (Astuti et al., 2014). There are some evidence of DF incidence being associated with seasonal variation, where higher DF incidence commonly occurred at the end of the rainy season (March-April). Concurrent findings come from Ariati et al. (2014), who developed a climate-based prediction model for hemorrhagic DF in Bogor city. In our study, it was clear that most clusters occurred in the first quarter of the year.

This report should be seen as pilot study as our results do not estimate RR precisely due to lack of information on some influential aspects, i.e. vector density and related environmental and socioeconomic characteristics, e.g. age, gender, immunity, land-use, and climate We also suggest that some analytical adjustments need to be considered in future works to obtain more comprehensive information as
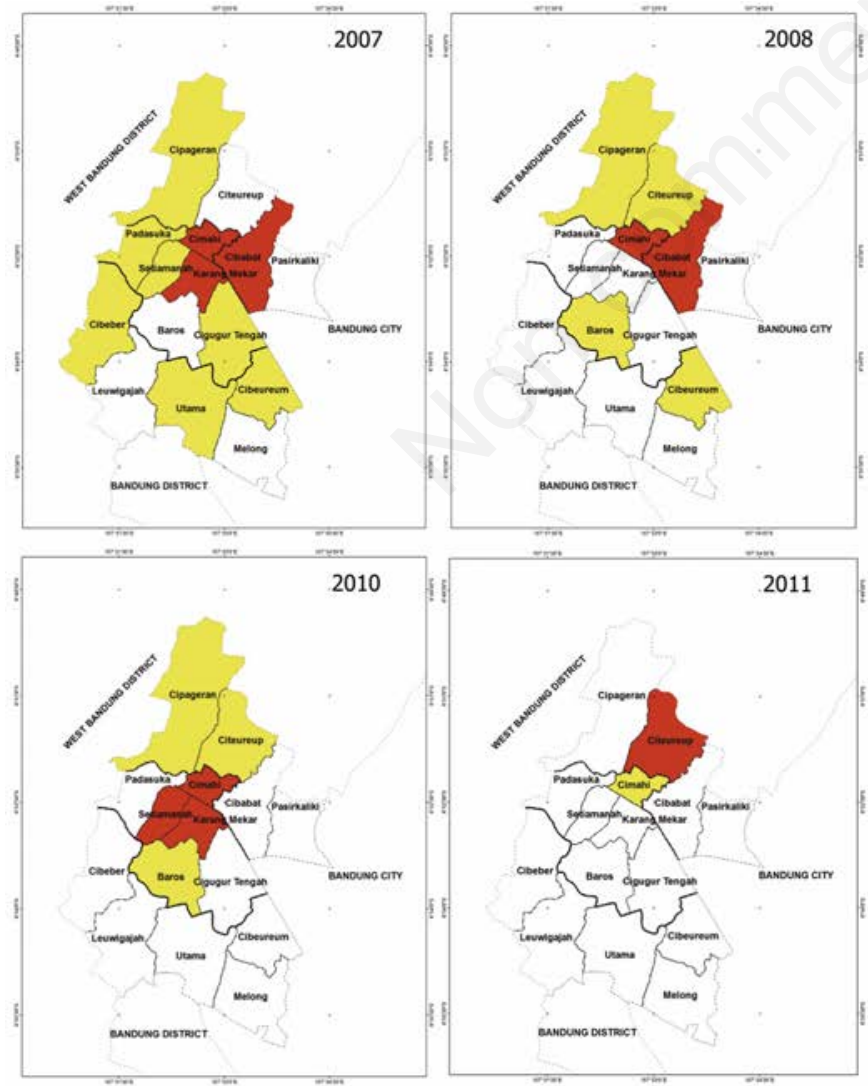
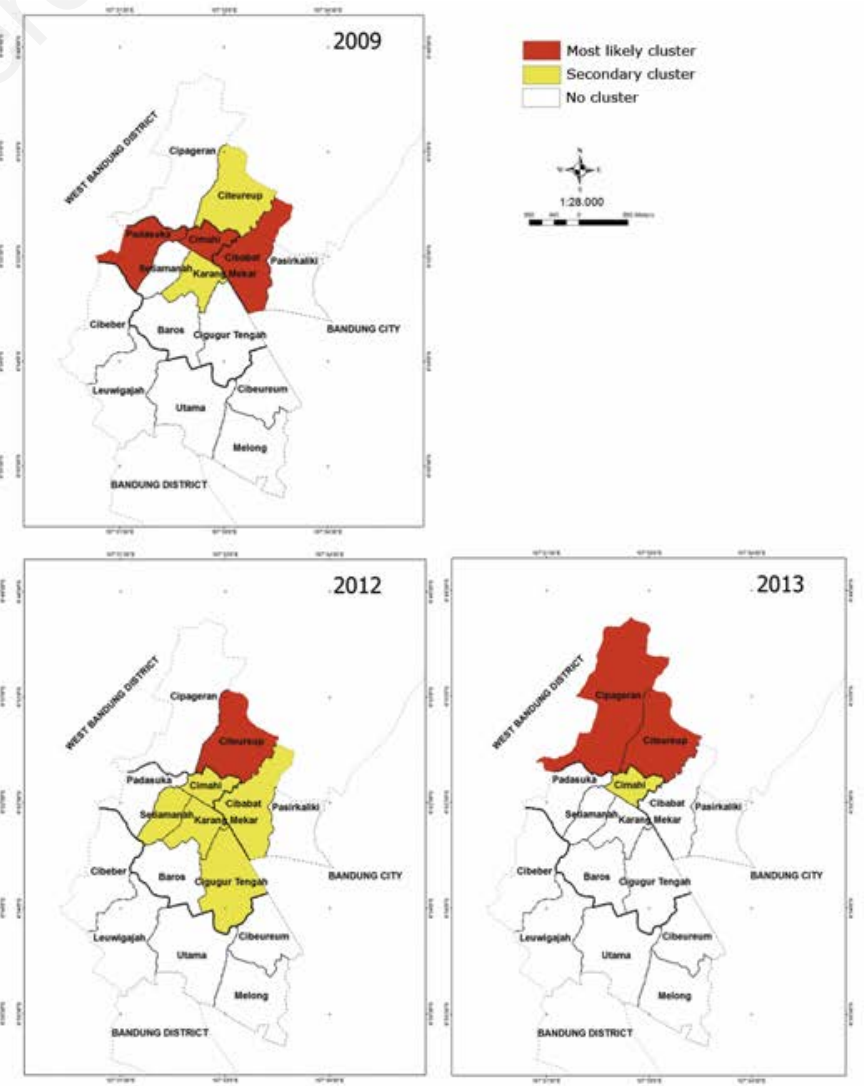

Figure 2. Clusters of dengue fever found during the period covered by the study. 
pointed out by Naish et al. (2014). However, our study has produced a perspective on DF incidence in an endemic region in Indonesia that can be used by local health managers and disease surveillance staff to monitor DF outbreaks and facilitate decisions on how to mount an effective intervention. This information would also be beneficial for communities by encouraging people's awareness with respect to their environment and preparedness to deal with DF outbreaks based on temporal trends. Another strong point is that we used the village-level as the smallest unit of analysis, which makes it possible to estimate inter-cluster RR risk in the area. The results presented thus have several implications for the current surveillance system and we recommend that: i) more active surveillance be routinely applied to monitor every change on DF epidemiology over time as suggested by WHO (2011); ii) GIS applications be used as operational supportive tools for projection and intervention with regard to areas at high risk for DF; iii) future studies to explore the major inter-related factors in a larger areas be considered to study outbreaks, which may have resulted from high migration over the districts; iv) our health system be strengthened in context of disease control and prevention by the creation of inter-sectoral partnerships involving health, education, environment and general affairs to provide better coordination with regard to infrastructure, housing and demography resulting in a big picture of DF distribution pattern and allowing in-depth analysis.

\section{Conclusions}

Twenty-four statistically significant DF clusters were identified in the 2007-2013 period. Clusters were most frequently detected as in the first 4-year period of study in the villages Cibabat and Cimahi, whereas Citeureup emerged as a high-risk cluster in 2011-2013. Importantly, DF clustering was more often observed in the first quarter of each year and there should be a tendency of spread from the centre to the northern part of Cimahi City. Future research on risk factors is strongly recommended.

\section{References}

Alzahrani AG, Al Mazroa MA, Alrabeah AM, Ibrahim AM, Mokdad AH, Memish ZA, 2013. Geographical distribution and spatio-temporal patterns of dengue cases in Jeddah Governorate from 2006-2008. T Roy Soc Trop Med H 107:23-9.

Ariati J, Musadad A, 2013. The relationship of climate to dengue cases in Manado, North Sulawesi: 2001-2010. Available from: ejournal.litbang.depkes.go.id/index.php/HSJ//article/download/3092/3095

Ariati J, Musadad A, 2014. Prediction model event Dengue Haemorrhagic Fever (DHF) based on climate factor in Bogor, West Java (In Bahasa Indonesia). Bul Penelit Kesehat 42:249-56.

Arunachalam N, Tana S, Espino F, Kittayapong P, Abeyewickrem W, Wai KT, Tyagi BK, Kroeger A, Sommerfeld J, Petzold M, 2010. Eco-biosocial determinants of dengue vector breeding: a multicountry study in urban and periurban Asia. B World Health Organ 88:17384.

Astuti E, Ipa M, Pradani F, 2014. Resistence detection of Aedes aegypti larvae to cypermethrin from endemic area in Cimahi City West Java. Aspirator 6:7-12.

Astutik S, Rahayudi B, Iskandar A, Fitriani R, Murtini S, 2011. Detection of spatial-temporal autocorrelation using multivariate
Moran and Lisa method on Dengue Hemorrhagic Fever (DHF) incidence, East Java, Indonesia. Eur J Sci Res 49:279-85.

Åström C, Rocklöv J, Hales S, Béguin A, Louis V, Sauerborn R, 2012. Potential distribution of dengue fever under scenarios of climate change and economic development. EcoHealth 9:448-54.

Attaway DF, Jacobsen KH, Falconer A, Manca G, Waters NM, 2014. Assessing the methods needed for improved dengue mapping: a SWOT analysis. Pan Afr Med J 17:289.

Banu S, Hu W, Hurst C, Guo Y, Islam MZ, Tong S, 2012. Space-time clusters of dengue fever in Bangladesh. Trop Med Int Health 17:108691 .

Banu S, Hu W, Hurst C, Tong S, 2011. Dengue transmission in the AsiaPacific region: impact of climate change and socio-environmental factors. Trop Med Int Health 16:598-607.

Benedict MQ, Levine RS, Hawley WA, Lounibos LP, 2007. Spread of the tiger: global risk of invasion by the mosquito Aedes albopictus. Vector-Borne Zoonot 7:76-85.

Bhatt S, Gething PW, Brady OJ, Messina JP, Farlow AW, Moyes CL, Drake JM, Brownstein JS, Hoen AG, Sankoh 0, Myers MF, George DB, Jaenisch T, Wint GRW, Simmons CP, Scott TW, Farrar JJ, Hay SI, 2013. The global distribution and burden of dengue. Nature 496:504-7.

Bi Y, Hu W, Yang H, Zhou XN, Yu W, Guo Y, Tong S, 2013. Spatial patterns of malaria reported deaths in Yunnan Province, China. Am J Trop Med H 88:526-35.

Bouzid M, Colón-González FJ, Lung T, Lake IR, Hunter PR, 2014. Climate change and the emergence of vector-borne diseases in Europe: case study of dengue fever. BMC Public Health 14:781.

Bureau of Statistics of Indonesia, 2014. Statistical Yearbook of Indonesia 2015. BPS-Statistics Indonesia, Jakarta, Indonesia.

Cheong Y, Ling OG, Kramer A, Lakes T, 2014. Spatio-temporal patterns of dengue in Malaysia: combining address and sub-district level. Geospat Health 9:131-40.

Cimahi Municipal Bureau of Statistics, 2014. Cimahi City in Figure 2014. Cimahi Municipal Bureau of Statistics, Cimahi, Indonesia.

Cimahi Municipal Health Office, 2014. Cimahi Health Profile 2014 (In Bahasa Indonesia). Cimahi Municipal Health Office, Cimahi, Indonesia.

Dhimal M, Ahrens B, Kuch U, 2015. Climate change and spatiotemporal distributions of vector-borne diseases in Nepal. A systematic synthesis of literature. PLoS One 10:e129869.

Gubler D, 2011. Dengue, urbanization and globalization:the unholy trinity of the 21st century. Trop Med Int Health 39:3-11.

Guzman MG, Halstead SB, Artsob H, Buchy P, Farrar J, Gubler DJ, Hunsperger E, Kroeger A, Margolis HS, Martinez E, Nathan MB, Pelegrino JL, Simmons C, Yoksan S, Peeling RW, 2010. Dengue: a continuing global threat. Nat Rev Microbiol 8:7-16.

Jeefoo P, Tripathi NK, Souris M, 2010. Spatio-temporal diffusion pattern and hotspot detection of dengue in Chachoengsao Province, Thailand. Int J Environ Res 8:51-74.

Johansson MA, Dominici F, Glass GE, 2009. Local and global effects of climate on dengue transmission in Puerto Rico. PLoS Neglect Trop D 3:e382.

Kulldorff M, Athas WF, Feuer EJ, Miller BA, Key CR, 1998. Evaluating cluster alarms: a space-time scan statistic and brain cancer in Los Alamos. Am J Public Health 88:1377-80.

Kulldorff M, Nagarwalla N, 1995. Spatial disease clusters: detection and inference. Stat Med 14:799-810.

Lang J, 2009. Recent progress on sanofi pasteur's dengue vaccine candidate. J Clin Virol 46:20-4.

Li Z, Yin W, Clements A, Williams G, Lai S, Zhou H, Zhao D, Guo Y, 
Zhang Y, Wang J, Hu W, Yang W, 2012. Spatiotemporal analysis of indigenous and imported dengue fever cases in Guangdong province, China. BMC Infect Dis 12:132.

McMichael AJ, Woodruff RE, Hales S, 2006. Climate change and human health: present and future risks. Lancet 367:859-69.

Ministry of Health of Indonesia, 2014. Indonesia Health Profile 2013 (In Bahasa Indonesia). Ministry of Health of Indonesia, Jakarta, Indonesia.

Morrison AC, Getis A, Santiago M, Rigau-Perez JG, Reiter P, 1998. Exploratory space-time analysis of reported dengue cases during an outbreak in Florida, Puerto Rico, 1991-1992. Am J Trop Med H 58:287-98.

Naish S, Dale P, Mackenzie J, McBride J, Mengersen K, Tong S, 2014. Climate change and dengue: a critical and systematic review of quantitative modelling approaches. BMC Infect Dis 14:167.

Oki M, Yamamoto T, 2012. Climate change, population immunity, and hyperendemicity in the transmission threshold of dengue. PLoS One 7:e48258.

Porter KR, Beckett CG, Kosasih H, Tan RI, Alisjahbana B, Rudiman PIF, Widjaja S, Listiyaningsih E, Ma'roef CN, McArdle JL, 2005. Epidemiology of dengue and dengue hemorrhagic fever in a cohort of adults living in Bandung, West Java, Indonesia. Am J Trop Med H 72:60-6.

Pradani F, Fuadiyah MEA, Yuliasih Y, 2010. People behavior and entomological index of Dengue vector in Cimahi city (In Bahasa Indonesia). Aspirator 2:37-44.

Prasetyowati H, Santya R, 2012. DHF cases dominated by DEN-3 serotype in the West Java Province. Available from: ejournal.litbang.depkes.go.id/index.php/HSJ//article/view/422/103

Rahmaniati M, Eryando T, Susanna D, Pratiwi D, Nugraha F, Riandi MU, 2014. The utilization of Standard Deviational Ellipse (SDE) model for the analysis of dengue fever cases in Banjar City, Indonesia. Available from: www.globalilluminators.org/wp-content/uploads/2014/12/ITMAR-14-137.pdf

Ruliansyah A, Gunawan T, Juwono S, 2011. Utilization of remote sensing image and Geograhic Information System to mapping vulnerable areas to Dengue Hemorrhagic Fever (DHF) (Case study in
Pangandaran sub-district, Ciamis, West Java) (In Bahasa Indonesia). Aspirator 3:72-81.

Ruliansyah A, Yuliasih Y, Hasbullah S, 2014. Utilization of ASTER image in the determination and verification Dengue Hemorrhagic Fever (DHF) prone areas in Banjar city, West Java (In Bahasa Indonesia). Aspirator 6:55-62.

SaTScan, 2015. Software for the spatial, temporal, and space-time scan statistics. Version 9.4, 2015. Information Management Services Inc., Boston, MA, USA. Available from: http://www.satscan.org/

Schmidt W-P, Suzuki M, Dinh Thiem V, White RG, Tsuzuki A, Yoshida LM, Yanai H, Haque U, Huu Tho L, Anh DD, Ariyoshi K, 2011. Population density, water supply, and the risk of dengue fever in Vietnam: cohort study and spatial analysis. PLoS Med 8:e1001082.

Strickman D, Sithiprasasna R, Kittayapong P, Innis BL, 2000. Distribution of dengue and Japanese encephalitis among children in rural and suburban Thai villages. Am J Trop Med H 63:27-35.

Sumarmo, 1987. Dengue haemorrhagic fever in Indonesia. SE Asian J Trop Med 18:269-74.

Toan do TT, Hu W, Quang Thai P, Hoat LN, Wright P, Martens P, 2013. Hot spot detection and spatio-temporal dispersion of dengue fever in Hanoi, Vietnam. Glob Health Action 6:18632.

Touray K, Adetifa IM, Jallow A, Rigby J, Jeffries D, Cheung YB, Donkor S, Adegbola RA, Hill PC, 2010. Spatial analysis of tuberculosis in an Urban West African setting: is there evidence of clustering? Trop Med Int Health 15:664-72.

Wearing H, Rohani P, 2006. Ecological and immunological determinants of dengue epidemics. P Natl Acad Sci USA 103:11802-7.

Weiss RA, McMichael AJ, 2004. Social and environmental risk factors in the emergence of infectious diseases. Nat Med 10:70-6.

WHO, 2011. Comprehensive guidelines for prevention and control of dengue and dengue haemorrhagic fever. WHO SEARO, New Delhi, India.

Wu W, Guo J, Guan P, Sun Y, Zhou B, 2011. Clusters of spatial, temporal, and space-time distribution of hemorrhagic fever with renal syndrome in Liaoning Province, Northeastern China. BMC Infect Dis 11:229. 